\title{
THE SHAREHOLDER'S RIGHT TO INFORMATION: NOVELLAES
}

\author{
Daniil A. Salikov \\ Volgograd State University, Volgograd, Russian Federation
}

Introduction: the article examines the changes in the order and grounds for providing the shareholders with access to information on the economic activities of the company. The possession of the information contained in the company's documents is the basis for making a decision on the agenda of the general meeting of the shareholders. The purpose of the study is to determine the positive and negative consequences of the changes in the rules of law governing the procedure, conditions and grounds for access to the information about the activities of the company. Methods: the methodological framework for the study is the systematic, comparative law methods and the method of analysis of the current and previous legislation, as well as the method of legal forecasting of the impact of changes on the structure and content of the legal relations between the shareholder and the joint stock company. Results: it is proved that the introduction of the categories of "business purpose" and its "reasonableness", as well as the grounds for refusal to provide the information with an unreasonable request of the shareholder, complicates the procedure of acquaintance with the information, which allows us to effectively combat the abuse of rights, at the same time, there is an additional obligation of the shareholders - to prove their integrity. Conclusions: the procedure and conditions for providing access to information should continue to be adjusted systematically, based on the general principles of the civil legislation and special rules of the sectoral legislation. It is recommended that the shareholders- minority shareholders widely apply the shareholder's agreements, including the provisions for the exchange of information, coordination of voting, support and cooperation.

Key words: share, joint stock company, shareholder, minority shareholder, law, information, business purpose, reasonableness.

Citation. Salikov D.A. The Shareholder's Right to Information: Novellaes. Legal Concept, 2018, vol. 17, no. 4, pp. 108-112. DOI: https://doi.org/10.15688/lc.jvolsu.2018.4.15

УДК 347.457 .1

Дата получения статьи: 07.09.2018

ББК 67.404 .2

Дата принятия статьи: 22.10.2018

\section{ПРАВО АКЦИОНЕРА НА ИНФОРМАЦИЮ: НОВЕЛЛЫ ЗАКОНОДАТЕЛЬСТВА}

\author{
Даниил Александрович Саликов \\ Волгоградский государственный университет, г. Волгоград, Российская Федерация
}

\begin{abstract}
Введение: в статье исследуются изменения порядка и оснований предоставления акционерам доступа к информации о хозяйственной деятельности общества. Владение сведениями, содержащимися в общественных документах, является основой принятия того или иного решения по вопросу повестки общего собрания акционеров. Цель исследования состоит в определении позитивных и негативных последствий внесения изменений в нормы права, регламентирующие порядок, условия и основания доступа к информа$\infty$ ции о деятельности акционерного общества. Методы: методологическую основу составляют системный и сравнительно-правовой методы, метод правового прогнозирования влияния изменений на структуру и содержание правоотношений между акционером и акционерным обществом, а также анализа действующего и ранее действующего законодательства. Результаты: дается обоснование того, что введение категорий «деловая цель» и ее «разумность», а также оснований отказа в предоставлении информации при необоснованном требовании акционера усложняет процедуру ознакомления со сведениями, что позволяет эффективно бороться с злоупотреблениями правом. Вместе с тем возникает дополнительная обязанность акционеров доказать свою добросовестность. Выводы: порядок и условия предоставления доступа к информации сле-
\end{abstract}


дует продолжать корректировать системно, основываясь на общих началах гражданского законодательства и специальных нормах отраслевого законодательства. Акционерам-миноритариям рекомендуется широко применять акционерные соглашения, включая в них положения об обмене информации, координации голосования, содействии и сотрудничестве.

Ключевые слова: акция, акционерное общество, акционер, миноритарий, право, информация, деловая цель, разумность.

Цитирование. Саликов Д. А. Право акционера на информацию: новеллы законодательства // Legal Concept= Правовая парадигма. - 2018. - Т. 17, № 4. - C. 108-112. - DOI: https://doi.org/10.15688/lc.jvolsu.2018.4.15

\section{Введение}

Сведения о сделках, совершенных обществом, итогах общих собраний, решениях, принимаемых правлением, аффилированных лицах и другая важная информация - источник формирования у акционера видения стратегии управления обществом. Необходимость в получении доступа к внутренней информации общества профессор А.И. Гончаров объясняет следующим образом: «Для формирования собственной позиции по какому-то вопросу, который касается акционерного общества, акционер имеет право на о3накомление с его хозяйственной документацией» $[1$, с. 83]. Однако процедура получения таких сведений кроет в себе множество возможностей манипулирования и противодействий.

Как известно, акционеры делятся на миноритарных и мажоритарных владельцев обыкновенных акций. Нередко между этими двумя группами возникают конфликты, приводящие к злоупотреблению правом и нарушениям законодательства. Распространены случаи, когда миноритарии могут требовать предоставить копии огромного количества документов, счет которых иногда идет на десятки и сотни тысяч экземпляров [4, с. 451]. В таком случае наносится материальный ущерб и осложняется работа отдельных отделов организации, что может привести к снижению эффективности труда.

Как верно отмечает А.С. Демченко: «Вследствие пробелов законодательства не всегда асоциальные действия приобретают противоправный характер, поскольку за рамками действующих правовых норм остается значительное количество социально-негативных форм поглощений и шантажа, и, как результат, такие формы считаются правовыми» [2, c. 86].
Ярким примером подобных конфликтов может служить дело между ООО «Прожектор» и ПАО «Транснефть». Первое приобрело акции второго. Новый миноритарий обратился в суд сначала с требованием предоставить документы за 5 лет, а затем и право голоса по привилегированным акциям, так как выплата была произведена по ним не в полном объеме [7]. Наконец, он попросил признать недействительной новую редакцию устава [6]. В итоге заявитель отказался от всех своих требований только после того, как доли в ООО «Прожектор» по данным ЕГРЮЛ перешли к новым собственникам.

Проблема правового регулирования получения достоверной информации носит междисциплинарный характер. Остро это проявляется в сфере наукоемких инновационных проектов, где требуется незамедлительная, выраженная в правовых действиях реакция акционеров на развитие науки и рыночную конъектуру. Как отмечает профессор А.О. Иншакова: «Существенным же недостатком АО как актора наноиндустрии является невовлеченность всех держателей акций в управление хозяйствующим субъектом, так как миноритарные акционеры лишены возможности реального контроля деятельности инновационного субъекта...» [3, с. 87].

\section{Развитие законодательства о праве акционера на информацию}

В целях защиты сторон в корпоративных правоотношениях, связанных с доступом и предоставлением информации, 29 июля 2017 г. был принят Федеральный закон № 233-Ф3, вступивший в силу с 30 июля 2017 года [8].

В первую очередь редакции подверглись ст. 89 и ст. 91 Федерального закона от 26.12.1995 № 208-Ф3 «Об акционерных обществах» (далее - Закон об АО). Так, ранее ука- 
занный в п. 1 ст. 89 перечень документов, которые общество обязано хранить, устанавливается теперь ст. 91, которая детально в зависимости от пакета акций перечисляет виды источников информации. Ранее, напомним, п. 1 ст. 91 отсылал к п. 1 ст. 89 без разграничения по количеству акций. Примечательно то, что, как и в прежней редакции, доступ к протоколам заседаний правления и документам бухгалтерского учета может быть предоставлен только акционерам, владеющим не менее чем $25 \%$ акций. Однако процент количества последних теперь не является, как ранее, императивным и жестким, а наоборот, закон допускает установление меньшего процента уставом общества (п. 6 ст. 91) [9].

Термин «документы бухгалтерского учета» остался неизменным и не получил в рассматриваемом законе должного раскрытия. Вместе с тем на практике имеют место споры об относимости гражданско-правовых договоров к документам бухгалтерского учета, и, следовательно, могут ли запрашивать к ним доступ акционеры, владеющие пакетом акций менее чем $25 \%$. Точку в спорах поставил Верховный Суд Российской Федерации, путем анализа норм Федерального закона от 6 декабря 2011 г. № 402-Ф3 «О бухгалтерском учете» и норм Закона об АО, заключив, что бухгалтерские документы согласно Закону об акционерных обществах - это «любые документы, имеющие существенное значение для правильного ведения бухгалтерского учета, в том числе к ним относятся и гражданско-правовые договоры, которые в неразрывной связи с первичными учетными документами формируют бухгалтерский учет» [5]. Следовательно, акционеры, не обладающие соответствующим количеством акций, не вправе требовать к ним доступ. Новая редакция ст. 91 Закона об АО не разрешила данной проблемы, оставляя этот вопрос на усмотрение правоприменителя.

Позитивным началом для публичных обществ можно отметить закрытый перечень запрашиваемых документов. Теперь четко урегулирован вопрос о том, кому и какие документы могут быть предоставлены согласно закону, а не уставу или внутренним документам публичного общества. Однако данные правила касательно непубличных обществ применяются только в том случае, если иной порядок и условия предоставления доступа не установлен уставом непубличного общества. Причем принятие решения о таких положениях при учреждении или внесении изменений в устав должно быть принято единогласно, что, с одной стороны, на практике может осложнить данный процесс, а с другой предоставляет большую автономию и независимость от норм закона непубличным акционерным обществам.

Настоящей новеллой является введение «деловой цели», с которой запрашиваются документы и информация относительно крупных сделок и сделок с заинтересованностью, протоколы заседаний совета директоров, отчеты оценщиков имущества, иные сведения, предусмотренные уставом и другими актами, разработанные одним или несколькими акционерами, владеющими менее $25 \%$ акций.

Что же такое деловая цель? Согласно п. 7 ст. 91 Закона об АО под данным термином понимается «законный интерес акционера в получении сведений и документов, которые объективно необходимы и достаточны для надлежащей реализации прав акционера, предусмотренных указанным законом» [9]. Закон перечисляет случаи, когда деловая цель не считается разумной: есть основания полагать о недобросовестности акционера; имеет место необоснованный интерес к такой информации; акционер является конкурентом либо аффилированным лицом конкурента.

Учитывая вышеизложенное и обращая внимание на п.п. 4 п. 8 ст. 91 Закона об АО (основание отказа в доступе), который подчеркивает обязанность акционера, обратившегося с требованием предоставить документы, можно заключить, что акционер теперь обязан доказывать деловую цель и ее разумность, путем их указания в требовании. Думается, такое положение противоречит основам гражданского законодательства, поскольку корпоративные правоотношения выделяются из гражданско-правовых и на них распространяется презумпция добросовестности (п. 3 ст. 1 Гражданского кодекса Российской Федерации).

\section{Выводы}

Таким образом, новая редакция ст. 91 Закона об АО наделяет общество правом от- 
каза в предоставлении доступа к информации, которое корреспондирует обязанности акционера обосновать свое требование, доказать деловую цель и ее разумность в пределах, прямо указанных Законом. Из этого следует, что введение таких правил, как «деловая цель» и «основания отказа для предоставления информации», вводят в данный институт элементы доказывания добросовестности, что противоречит основным началам гражданского права, а также фактически означает «перекос» в сторону органов управления (менеджмента) в ущерб правам и законным интересам добросовестных акционеров, которые ставятся в зависимость от органов управления.

С одной стороны, законодатель справился с задачей по борьбе с злоупотреблениями миноритариев при реализации права на информацию, введя ужесточенные требования по порядку и основаниям предоставления информации, с другой - акционеры (миноритарии) как собственники доли в капитале общества лишаются свободного доступа к информации и наделяются взамен обязанностью доказать свою добросовестность.

Для исправления указанных несоответствий рекомендуется продолжать совершенствование формулировок и структур правовых норм, регламентирующих право акционера на информацию о деятельности общества. В целях защиты корпоративных прав миноритарных акционерам предлагается заключать акционерные соглашения, в которых необходимо предусматривать положения о голосовании на общем собрании, об обмене информацией, содействии и сотрудничестве, а также используемых средствах защиты прав.

\section{СПИСОК ЛИТЕРАТУРЫ}

1. Гончаров, А. И. Акция как бездокументарная ценная бумага / А. И. Гончаров // Вестник Волгоградского государственного университета. Серия 5, Юриспруденция. -2014 . - № 2. - С. 80-85.

2. Демченко, А. С. Правовые способы защиты от «недружественных поглощений» в РФ / А. С. Демченко // Актуальные проблемы российского права. 2015. -№ 8. - С. 84-90.
3. Иншакова, А. О. Преимущественные формы корпоративного хозяйствования в сфере наноиндустрии: ООО и АО / А. О. Иншакова // Наука и образование: хозяйство и экономика; предпринимательство; право и управление. - 2016 -№ 1 (68). C. 83-87.

4. Корпоративное право / Е. Г. Афанасьева [и др.] ; отв. ред. И. С. Шиткина. - 2-е изд., перераб. и доп. - М. : Кнорус, 2015. - 527 с.

5. Обзор судебной практики Верховного Суда Российской Федерации № 3 (2017) : (утв. Президиумом Верховного Суда РФ 12.07.2017) // Солидарность. -2017. - № 26.

6. Определение Арбитражного Суда г. Москвы от 20.07.2016 по делу № А40-51755/2016. - Доступ из справ.-правовой системы «КонсультантПлюс».

7. Решение Арбитражного суда г. Москвы от 28.04.2016 по делу № А40-195690/2015. - Доступ из справ.-правовой системы «КонсультантПлюс».

8. Федеральный закон «О внесении изменений в Федеральный закон “Об акционерных обществах" и статью 50 Федерального закона "Об обществах с ограниченной ответственностью"» от 29 июля 2017 г. № 233-Ф3 // Собрание законодательства Российской Федерации. - 2017. - 31 июля (№ 31). - Ст. 4782.

9. Федеральный закон «Об акционерных обществах» от 26 декабря 1995 № 208-Ф3 : (ред. от 19 июля 2018) // Российская газета. - 1995. - 29 дек. (№ 248).

\section{REFERENCES}

1. Goncharov A.I. Aktsiya kak bezdokumentarnaya tsennaya bumaga [Stock as a Non-Documentary Security]. Vestnik Volgogradskogo gosudarstvennogo universiteta. Seriya 5, Yurisprudentsiya [Science Journal of Volgograd State University. Jurisprudence], 2014, no. 2, pp. 80-85.

2. Demchenko A.S. Pravovye sposoby zashchity ot «nedruzhestvennykh pogloshcheniy» v RF [Legal Ways to Protect against "Unfriendly Takeovers" in the Russian Federation]. Aktualnye problemy rossiyskogo prava, 2015, no. 8, pp. 84-90.

3. Inshakova A.O. Preimushchestvennye formy korporativnogo khozyaystvovaniya $\mathrm{V}$ sfere nanoindustrii: OOO i AO [Primary Forms of Corporate Management in the Sphere of Nanoindustry: LLC and JSC]. Nauka i obrazovanie: khozyaystvo i ekonomika; predprinimatelstvo; pravo i upravlenie, 2016, no. 1 (68), pp. 83-87.

4. Afanasyeva E.G., et al. Korporativnoe pravo [Corporate Law]. Moscow, Knorus Publ., 2015. 527 p.

5. Obzor sudebnoy praktiki Verkhovnogo Suda Rossiyskoy Federatsii № 3 (2017) (utv. Prezidiumom 


\section{ВОПРОСЫ ЧАСТНОПРАВОВОГО РЕГУЛИРОВАНИЯ}

Verkhovnogo Suda RF 12.07.2017) [Review of Judicial Practice of the Supreme Court of the Russian Federation no. 3, 2017 (Approved by the Presidium of the Supreme Court of the Russian Federation on 12 July 2017)]. Solidarnost, 2017, no. 26.

6. Opredelenie Arbitrazhnogo Suda g. Moskvy ot 20.07.2016 po delu № A40-51755/2016 [Resolution of the Arbitration Court of Moscow of 20 July 2016 on Case No. A40-51755/2016]. Access from Reference Legal System "Konsultant Plyus".

7. Reshenie Arbitrazhnogo suda g. Moskvy ot 28.04.2016 po delu № A40-195690/2015 [Decision of the Arbitration Court of Moscow of 28 April 2016 on Case No. A40-195690/2015]. Access from Reference Legal System "Konsultant Plyus".
8. Federalnyy zakon «O vnesenii izmeneniy v Federalnyy zakon «Ob aktsionernykh obshchestvakh» i statyu 50 Federalnogo zakona «Ob obshchestvakh s ogranichennoy otvetstvennostyu» ot 29 iyulya $2017 \mathrm{~g}$. № 233-FZ [Federal Law “On Amendments to the Federal Law "On Joint-Stock Companies" and Article 50 of the Federal Law "On Limited Liability Companies" of 29 July 2017 No. 233-FZ]. Sobranie zakonodatelstva $R F$ [Collected Legislation of the Russian Federation], 2017, Jule 31, no. 31, art. 4782.

9. Federalnyy zakon «Ob aktsionernykh obshchestvakh» ot 26 dekabrya 1995 № 208-FZ: (red. ot 19 iyulya 2018) [Federal Law 'On Joint-Stock Companies' of 26 December 1995 No. 206-FZ]. Rossiyskaya gazeta, 1995, Dec. 29, no. 248.

\section{Information about the Author}

Daniil A. Salikov, Master Student, Department of Civil and International Private Law, Volgograd State University, Base Department of the Southern Scientific Center of Russian Academy of Sciences, Prosp. Universitetsky, 100, 400062 Volgograd, Russian Federation, gimchp@volsu.ru, https://orcid.org/ 0000-0002-4345-9909

\section{Информация об авторе}

Даниил Александрович Саликов, магистрант кафедры гражданского и международного частного права, Волгоградский государственный университет, базовая кафедра ЮНЦ РАН, просп. Университетский, 100, 400062 г. Волгоград, Российская Федерация, gimchp@volsu.ru, https://orcid.org/ 0000-0002-4345-9909 